\title{
Sectarianism and the Ambiguities of Welfare in Lebanon
}

\section{Citation}

Cammett, Melani. 2015. "Sectarianism and the Ambiguities of Welfare in Lebanon." Current Anthropology 56 (S11) (October): S76-S87. doi:10.1086/682391.

\section{Published Version}

doi:10.1086/682391

\section{Permanent link}

http://nrs.harvard.edu/urn-3:HUL.InstRepos:34786373

\section{Terms of Use}

This article was downloaded from Harvard University's DASH repository, and is made available under the terms and conditions applicable to Other Posted Material, as set forth at http:// nrs.harvard.edu/urn-3:HUL.InstRepos:dash.current.terms-of-use\#LAA

\section{Share Your Story}

The Harvard community has made this article openly available.

Please share how this access benefits you. Submit a story. 


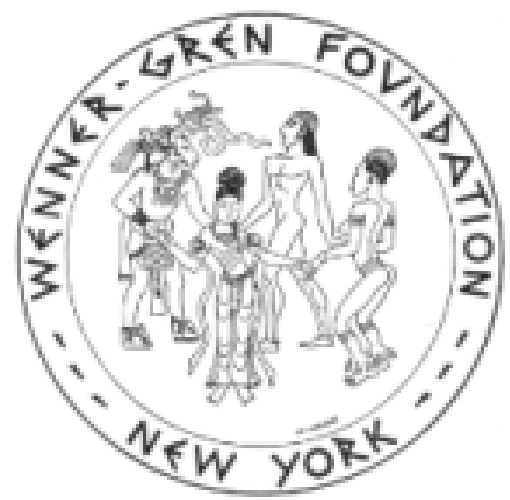

Sectarianism and the Ambiguities of Welfare in Lebanon

Author(s): Melani Cammett

Source: Current Anthropology, (-Not available-), p. S000

Published by: The University of Chicago Press on behalf of Wenner-Gren Foundation for

Anthropological Research

Stable URL: http://www.jstor.org/stable/10.1086/682391

Accessed: 01/11/2015 16:07

Your use of the JSTOR archive indicates your acceptance of the Terms \& Conditions of Use, available at

http://www.jstor.org/page/info/about/policies/terms.jsp

JSTOR is a not-for-profit service that helps scholars, researchers, and students discover, use, and build upon a wide range of content in a trusted digital archive. We use information technology and tools to increase productivity and facilitate new forms of scholarship. For more information about JSTOR, please contact support@jstor.org.

The University of Chicago Press and Wenner-Gren Foundation for Anthropological Research are collaborating with JSTOR to digitize, preserve and extend access to Current Anthropology. 


\title{
Sectarianism and the Ambiguities of Welfare in Lebanon
}

\author{
by Melani Cammett
}

\begin{abstract}
Nonstate providers are often more important in the everyday lives of the poor than outposts of the state. In this essay, I focus on one type of provider, sectarian organizations, which are an integral component of politics and welfare regimes in parts of the Middle East and other developing regions. Focusing on Lebanon, I describe how sectarian welfare providers emerge from and help to constitute political sectarianism while tracing what is at stake for the poor. First, by holding public offices and dominating informal channels that mediate access to public benefits, these actors mediate the experience of accessing the "rights" of citizenship. Second, while they provide benefits and services that might not otherwise be available, the modes of allocating welfare by sectarian parties can be discriminatory, notably along partisan and religious lines. Third, sectarian groups politicize the process of accessing social benefits while undercutting the political voice of the poor by weakening alternative channels of claim making. Finally, the crosscutting effects of sectarian organizations in welfare regimes suggest additional challenges to boosting local participation in development policy: while they are deeply embedded in the communities they serve, they produce and reinforce social inequalities.
\end{abstract}

\section{Introduction}

In the past decade, a growing body of research analyzes the origins and diversity of welfare regimes in the global south. Much of this work focuses on the role of the state in assuring social protection and providing or regulating the provision of social services (Brooks 2009; Haggard and Kaufman 2008; Rudra 2008; Seekings 2008) or on the growing importance of international NGOs (Fox and Brown 1998; Mercer 2002; Tearney 2007). Yet the landscape of providers is far more variegated, and the boundary between state and nonstate actors in the realm of welfare is far more porous than such accounts imply (Cammett and MacLean 2014; Gough and Wood 2004). A wide variety of local actors offer basic services and help people to manage lifecycle risks. These range from more formalized institutions, such as private firms and local NGOs, charities, and faith-based organizations, to more informal arrangements, such as the family and friendship networks, middlemen who broker access to services from thirdparty providers, and hometown associations, among others. In the context of weak state capacity and uneven state penetration of national territories, nonstate providers are far more important in the everyday lives of many people in the global south than outposts of the state or representatives of

Melani Cammett is Professor in the Department of Government at Harvard University (1737 Cambridge Street, Cambridge, Massachusetts 02138, U.S.A. [mcammett@gov.harvard.edu]). This paper was submitted 4 VIII 14, accepted $26 \mathrm{~V} \mathrm{15}$, and electronically published 10 IX 15. public agencies. Providers often straddle the formal boundaries between the public and private spheres, rendering this distinction less meaningful for those who seek and benefit from their services than it appears to social scientists who expressly study the state and public policies.

In this paper I focus on one type of provider, sectarian organizations, which are an integral component of politics and welfare regimes in parts of the Middle East, South Asia, and Southeast Asia, at a minimum. Based on research in Lebanon (Cammett 2014; Cammett and Issar 2010), I describe how social service providers linked to sectarian groups both emerge from and continually help to constitute political sectarianism and to trace what is at stake for the poor as a result of these groups' involvement in the welfare regime. I highlight the ambiguities that emerge from their participation in the Lebanese welfare regime and their effects on access to social services. I make four main observations. First, by holding public offices and dominating informal channels that mediate access to public benefits, these actors blur the boundaries between the state and nonstate realms. In this way, they act at the "margins of the state," setting up other forms of order and regulation that affect the way citizens "secure their survival" (Das and Poole 2004:8) and in so doing mediate the experience of accessing "rights." Second, sectarian parties at once serve as alleviators and perpetrators of structural violence: while they provide benefits and services that might not otherwise be available, their modes of allocating welfare can be discriminatory, notably along partisan and religious lines. Third, sectarian organizations politicize the process of accessing social benefits. At the same time, however, they un- 
dercut the political voice of the poor by weakening alternative channels of claim making. Finally, the crosscutting effects of sectarian organizations in welfare regimes suggest additional challenges to boosting local participation in development policy (Fung and Wright 2003; Hickey and Mohan 2004; Rao and Walton 2004). While they are deeply embedded in the communities they serve-and are often staffed by local residents - they produce and reinforce social inequalities.

Throughout the paper I focus on the politics of access to social welfare or struggles over the distribution of resources that enable people to meet their basic needs. A key question at stake here is who benefits from or who feels protected by the welfare programs and goods allocated by sectarian parties, which by definition are rooted in particular subsets of the national political community. With respect to socioeconomic status (SES), those who benefit from or attempt to access the goods and services of sectarian welfare agencies generally fall into poor or low-income categories. But those covered by these programs are not only the most materially deprived. In the context of the Lebanese welfare regimeand, indeed, in many welfare systems in developing countries-people exist in a state of precariousness regardless of whether or not they meet locally appropriate thresholds of poverty based on measures of income or asset ownership. To be sure, those who seek welfare from sectarian organizations are almost never well off, but neither are they necessarily poor in economic terms. Rather, they run the gamut from those who face absolute material hardship, including difficulties in meeting daily caloric needs, to those whose lives are relatively comfortable but who exist in a constant state of uncertainty about whether they can sustain their standards of living. This conceptualization entails a broader notion of the needy and vulnerable, offering a more accurate picture of many of the people who are included in or attempt to penetrate the welfare networks of sectarian parties.

\section{The Welfare Regime in Lebanon}

Unlike international NGOs, which are a relatively new actor in world politics and have received extensive attention in research on development (see Bebbington, Hickey, and Mitlin 2008; Edwards and Hulme 1996; Korten 1990; Lewis and Kanji 2009; Salamon and Sokolowski 1999; Smith and Lipsky 1993), sectarian parties emerge out of a long historical tradition of religious charity in the Middle East. However, they are not mere reincarnations of the religions institutions that supplied services under Ottoman or colonial rule (Fawaz 1994; Hanssen 2005; Singer 2008). Rather, they have adapted to and/or emerged out of a new national political context in which an ostensibly independent state is the focal point of power. In this section, I provide a brief overview of the role of sectarian parties in the Lebanese political system and welfare regime as crucial background for the broader points I make in the concluding section of the paper.
The political system in postindependence Lebanon entrenched preexisting patterns of political sectarianism established during the Ottoman and colonial periods (Makdisi 2000). The system stipulates that top government positions are allocated by sect and divides parliamentary and civil service positions according to a preestablished formula, initially with $60 \%$ reserved for Christians from diverse sects and $40 \%$ reserved for Muslims from distinct sects. After the civil war ended in 1990, this formula was renegotiated to yield an even split between Christians and Muslims. Similarly, the electoral system institutionalizes sectarian identity by allocating seats by sect at the district level according to formulas derived from the sectarian identities of registered voters on their official identity cards. ${ }^{1}$ In addition, religious authorities retain control over family law, governing core aspects of social and cultural life such as marriage, burial, and inheritance rules. The role of the state is also circumscribed in the economic realm: the Lebanese economy has long been founded on so-called laissez-faire principles, reflecting the interests of a small group of wealthy Maronite Christian and urban Sunni Muslim families (Gates 1998; Hudson 1968; Leenders 2004; Traboulsi 2007).

The sectarian political system has shaped the postindependence Lebanese welfare regime, which involves minimal if any state intervention and relies heavily on private, nonstate actors. During the administration of President Fu'ad Shihab (1958-1964), some attempts were made to expand the public welfare infrastructure, but not all were successful, and some initiatives were dismantled under the tenures of his successors. The Lebanese Civil war (1975-1990) led to the partial and, for some programs, total breakdown of public social welfare institutions, further weakening state administrative capacity. In part as a response to state failure, various groups from all of Lebanon's religious communities initiated or expanded their own social welfare programs while domestic and international NGOs proliferated in the domain of social provision (Corm 1991; Hanf 1993; Harik 1994). After the Ta'if Accords formally ended the war in 1989, some social welfare programs initiated by militias evolved into institutionalized welfare agencies with branch offices and networks of social centers. Organizations linked to political parties that either did not have militia wings during the war or did not emerge until the postwar period also launched their own welfare networks. ${ }^{2}$

1. In 2009 , the Lebanese government officially decreed that national identity cards were no longer required to list the sect of the bearer. In practice, most still retain this information, but this may change in the future.

2. Unlike their Sunni, Shi'a, and Druze counterparts, the Christian militias did not immediately transform wartime social institutions into postwar party institutions and welfare agencies largely because of the suppression of Christian leaders by Syria and its allies in Lebanon until the withdrawal of Syrian forces from Lebanon in 2005. 
Beyond the direct provision of services in their own or affiliated welfare agencies, sectarian parties provide aid for health and educational needs and food and financial assistance, and they act as intermediaries to facilitate access to citizen "entitlements." For example, citizens with demonstrated need are legally entitled to state coverage of up to $85 \%$ of hospitalization costs for the treatment of certain serious conditions. In practice, many cannot access this benefit largely because of soaring budget deficits accruing to the Ministry of Public Health. Thus, party representatives use connections to arrange government payment for the hospitalization costs of supporters. $^{3}$

Under these circumstances, the provision of social services is highly fragmented and underregulated even while the state takes on the largest role in financing social services. In this context, private actors enjoy ample opportunities to supply welfare and, more importantly, to take credit for statefunded benefits. Sectarian organizations, among others, therefore profit from state programs and financing yet have a vested interest in sustaining the underdevelopment of public welfare functions in the realms of provision and, especially, in the regulation of the system as a whole.

\section{The Politics of Access to Welfare}

The nature of the Lebanese welfare regime opens the door to political intermediation to access social benefits and services, including for obtaining public benefits. Even in forprofit health, educational, and other facilities, social and political connections can enable clients to obtain services at reduced prices. In Lebanon's patronage-based political system, connections to political organizations and politicians and demonstrated loyalty to a party constitute a vital strategy for gaining access to welfare (Cammett 2010; Chen and Cammett 2012). Some of the major parties, such as the predominantly Shi'a Hezbollah and the mainly Sunni Future Movement, run large networks of health clinics, dispensaries, hospitals, schools, and social assistance programs. ${ }^{4}$ Although their services are ostensibly open to all, their most ardent supporters receive preferential rates and generous benefits, including schooling for their children or medical care within their own institutions or in the facilities of third-party private providers. For example, like all parties, the Future Movement does not distribute equally to all. For the vast majority of its beneficiaries it provides minimal rewards, such as food boxes or onetime cash payments, that are usually associated

3. Author interviews of an official of the Amal Movement, Ghobeiry, January 17, 2008, and an official of the Ministry of Public Health, Beirut, June 13, 2006.

4. In recent years, the Future Movement has scaled back some of its programs, officially in order to rationalize and streamline its programs. Rumor has it that the organization has faced serious budget crises as a result of declining support from its historic patron, Saudi Arabia, and because of financial mismanagement. with "turnout-buying" efforts during elections. Core activists, who organize and attend meetings and demonstrations and participate in the life of the party, receive the most generous and continuous packages of benefits. A former employee of the Hariri Foundation noted, "For all welfare providers linked to parties, the families of members and supporters always get priority." 5

In other work, I use diverse forms of data and research methods to explore in more depth the ways in which sectarian organizations allocate social benefits, highlighting the political logic behind their distributional patterns (Cammett 2014). To summarize, I argue that a party's choice of political strategy, among other factors, influences which communities and people it targets with social benefits. When parties participate in formal political institutions and contest elections, they tend to reach out across communal lines and target beneficiaries beyond core supporters. ${ }^{6}$ When they prioritize forms of politics outside of formal institutional channels, such as orchestrating riots and organizing militias, they favor in-group members and, especially, their cadres and core activists. Thus, among other factors, overtly political decisions infuse the distribution of welfare goods, shaping the modes of access to social assistance.

It is well known in Lebanon that small-scale forms of material assistance, such as food and cash, are routinely deployed for electoral purposes, usually to reward existing supporters through "turnout buying" (Nichter 2008). Political participation, which for most people amounts to casting a ballot in national and local elections, is a virtual prerequisite for access to basic services supplied or facilitated by political parties as well as for the patronage of elected officials. A party representative joked about the exchange of votes for services in Lebanon: "In the United States, [providers] don't ask whether you are a Democrat or Republican before they give you a service. That's what they do here." To ensure that vote buying actually works, parties have devised elaborate and highly effective mechanisms for verifying individual and family voting behavior. But the provision of basic services is also used to reward and perhaps even induce other, nonelectoral forms of political behavior, such as participating in protests, riots, and sit-ins, or even serving in militias. Because sectarian organizations are embedded in

5. Author interview with a former employee of the Future Movement, Beirut, November 9, 2007.

6. I also argue that the nature of intracommunal politics shapes the welfare outreach of sectarian parties, particularly in power-sharing systems. Lebanon's political system compels coreligionist parties to outbid each other in an effort to gain monopoly representation over the in-group community. As a result, once a party has attained dominant status within its representative community, it is freer to cater to members of other communities.

7. Author interviews with an official of the Lebanese Forces, Beirut, January 21, 2008, and an official of the National Dialogue Party, Mazraa, November 2, 2007. 
the communities where they operate, they are well placed to monitor the political preferences and activities of local residents and to distribute material assistance to supporters on the grassroots level. ${ }^{8}$

In emphasizing the political logic of service provision, I acknowledge that motivations are difficult if not impossible to discern and are never unidimensional. I take seriously Ferguson's (1990) caution that "one cannot assume ... that a structure simply and rationally 'represents' or 'expresses' a set of 'objective interests'; one knows that structures are multilayered, polyvalent, and often contradictory, and that economic functions and 'objective interests' are always located within other, encompassing structures that may be invisible even to those who inhabit them" (17). Motivations and interests are not self-evident, even to the actors themselves. Although my arguments seem to impute interests to individuals and even to whole organizations, they should not be construed as suggesting that a single set of political goals drives the welfare programs of sectarian organizations. These groups may distribute or facilitate access to social services in order to fulfill altruistic commitments, present themselves as protectors and guarantors of well-being, gain supporters, or consolidate their control over territory and people, among other goals. At a minimum, political organizations calculate that service provision engenders political support, and this calculation factors into their motivations for offering services or arranging benefits. Furthermore, it is worth noting that my core claims are supported by diverse forms of evidenceincluding the statements of the actors in question - and reflect widespread local interpretations and perceptions of the welfare initiatives of the major sectarian parties. Indeed, a poll conducted in 2001 asked citizens who voted in the previous year's national elections to list the two most important factors shaping their vote choices. Over $50 \%$ of the sample listed the social service activities of the candidate among the two most important reasons for their vote (Chaoul, El-Hajj, and El-Khazen, et al. 2001). Politicians are cognizant of these expectations. In an interview in late 2007, a high-level political strategist for a major Christian political party noted, "We don't have services now. We're in the process of developing them.... But we know we need to help our supporters, especially now that we are constituting ourselves into a real political party. We know we have to start organizing ourselves to provide for our supporters."

It is important to stress that "buying support" through service provision is not exclusively an economic or material transaction, nor does it necessarily occur through direct ex-

8. Author interview with a member of the Progressive Socialist Party, Beirut, October 24, 2007; a Sunni woman, Hamra, Beirut, November 22, 2007; Sunni women, Sidon, November 24, 2007; Sunni women, Verdun, Beirut, December 2, 2007; and a Sunni woman, Tariq el Jedideh, December 4, 2007.

9. Author interview with a party official, Jounieh, Lebanon, October 30, 2007. changes. As in-depth interviews with citizens in Lebanon reveal, the receipt of services by an individual or by her family members or neighbors may compel some citizens to vote for the political party associated with the provider or to participate in demonstrations organized by the party. Even for these interviewees and for others, however, service provision can be interpreted as more than a material transaction. The sense of communal belonging embedded in the social welfare relationship has crucial psychological benefits, particularly in the context of underdeveloped and unstable national state institutions. The provider organization establishes itself as a source of social protection or a guardian of the community, and in so doing, it may garner popular allegiances. In particular, "bricks and mortar" welfare programs (Cammett and Issar 2010), which operate from fixed, physical locations in neighborhoods and villages, help to project the provider as a community guardian because they signal a long-term commitment to a geographic space and its inhabitants. Social service provision from bricks and mortar agencies, then, is distinct from cash payments or one-shot food distribution efforts, which predominate during electoral contests in some countries in the global south (Nichter 2008; Stokes 2005). Even if community members initially view the establishment of a welfare agency by a political party as a calculated move designed to win support, they may adopt a less cynical perspective on the party if the facility is maintained over time.

Welfare programs may also inspire support by individuals and families who have not received services but rather have witnessed or heard about the actions of providers in their communities and beyond. Service provision projects an image of "infrastructural power" (Mann 1984) as well as a commitment to protect that may garner the admiration or respect of observers and not just direct beneficiaries. This is especially valuable for a political organization that aims to build a reputation as a reliable and capable actor-one that is qualified to govern specific subnational territories or communities and ultimately the national state. Social service provision is not the sole means that political parties use to mobilize support, but it plays an important role where alternative sources of social protection are underdeveloped or absent.

Just as the motivations, interests, and goals of providers are multidimensional, beneficiaries too may have complex and not always congruent reasons for seeking and accepting assistance from sectarian organizations. For some, their overarching motive is simple-material need compounded by few and sporadic opportunities to meet their needs. The poor go to providers that offer them the services they need at a price they can afford. But insecurity in "middle-income" Lebanon does not necessarily entail insufficient financial resources; rather, it is to live in a state of tenuousness. Families may have sufficient resources to enjoy some comforts and may even send their children to private schools, but the precariousness of their existence is never far from their 
minds. The limited extent of health insurance coverage and its potential ramifications for household finances and wellbeing illustrates this point. As in many countries that lack universal health insurance or effective social safety nets, out of pocket health-care expenditures pose a major burden not only for the poor but also for middle-class families in Lebanon. Medical expenses can wipe out savings and force people to forego important needs, whether health related or otherwise. Furthermore, the informal sector accounts for the bulk of employment, which means that the majority of citizens do not benefit from health insurance and other benefits reserved for formal sector workers.

Even if socioeconomic need is the overarching consideration for most Lebanese who seek and accept services from providers linked to sectarian organizations, some emphasize that their relationship with these groups is not simply premised on a material quid pro quo. More fundamentally, the receipt of social assistance and services from sectarian providers may provide a sense of security and order that is missing in their lives. Political instability, ambiguities in laws and their enforcement, and the limited extent of social protection programs put many Lebanese in a state of vulnerability. A relationship with a patron - in this case, a representative of a sectarian party-helps to provide stability in their lives. Of course, this is a relationship of unequal power. Vulnerable families cannot demand entitlements; rather, they must work within existing hierarchies to piece together a way to meet their needs.

In analyzing the power relations embedded in the providerbeneficiary relationship, one might point out that sectarian providers are not obliged to serve all nor are they beholden to the general population. Unlike governments, sectarian organizations do not have a national mandate and have no apparent duty to serve or be accountable to those beyond their target groups, which are usually composed of in-group members and party members and supporters. Despite this, a "humanitarian" imperative appears to shape the discourse of welfare in Lebanon even among nongovernmental communal groups. Most representatives of the major sectarian parties insist that their organizations, unlike others, serve all without regard for religious or political affiliation. An apparent norm of nondiscrimination in service provision has developed, compelling the representatives of party-linked welfare agencies to justify social provision in moral terms. As in the contemporary world of global humanitarianism, a "discourse of affects and values offers a high political return" among the major Lebanese political actors who are in the welfare business (Fassin 2012:3).

Notwithstanding their inclusive rhetoric, the sectarian parties cannot and do not serve all. There is simply too much need for them to serve all in need, particularly outside of circumscribed territories. Data on residential populations in Beirut and Mount Lebanon, the two provinces where more than $50 \%$ of the total Lebanese population lives (i.e., "Greater Beirut"), suggest that at least in this part of the country, sectarian parties do not all establish welfare agencies in the neighborhoods and villages with the greatest need (Cammett 2014:106). A comparison of the socioeconomic status of the actual distribution of households with the socioeconomic status of the average distribution of the zones where welfare agencies linked to different parties and charities are located in the two provinces underscores this point. ${ }^{10}$ An analysis of the average distribution of households across distinct categories of SES in Beirut and Mount Lebanon provinces reveals that the smallest number of households can be classified as high SES while the majority fall in the lower-middle group followed by the upper-middle SES category. Yet there is considerable variation in the degree to which political parties and religious charities target lower-income households. Some parties and charities deviate considerably from the actual distribution of households in the two provinces by disproportionately targeting more upper-income neighborhoods in Greater Beirut. For example, at least within this part of the country, the predominantly Sunni Future Movement as well as Sunni charities differ most dramatically from the actual SES pattern by favoring upper-middle-income communities and serving fewer low-income areas than the regional average. Conversely, the Shi'a Hezbollah appears more responsive to SES within these two provinces, giving less attention to high- and upper-middle-income areas and placing the most emphasis on low-income areas of all groups, exceeding the regional average for this income category by a significant margin. After Hezbollah, the Shi'a Amal Movement appears most responsive to low-income areas. The Christian Kataeb Party favors lower-middle-income communities - even more than do Christian religious charities - but neglects the poorest areas in the Beirut-Mount Lebanon region.

Thus, data on household-level SES provide mixed support for the claim that the welfare outreach of political parties is motivated by socioeconomic need in this core region of the country. Not all the parties favor poor areas over others in the Greater Beirut region. Of course, the limited geographical scope of these data precludes more definitive assessments of the welfare outreach of sectarian parties on a national scale. Furthermore, this descriptive analysis cannot untangle the relationship between SES and sectarian endowments, which undoubtedly affects the results. For example, many predominantly Shi'a communities in Beirut and Mount Lebanon provinces are home to low-income families, which could explain why Shi'a political parties disproportionately target lowincome communities in this region.

Sectarian parties also serve distinct types of constituents in different ways. While some benefit from a generous array of services brokers provided by sectarian parties, others who are less integrated in partisan networks find themselves ex-

10. Lebanon has 1,644 zones, which are roughly equivalent to census tracts but refer to specific and familiar urban neighborhoods and villages. 
cluded. Differential experiences of human security result from these hierarchies: those who are inserted in political welfare networks are less vulnerable than those who are left out. This discretionary allocation of social welfare establishes and entrenches boundaries of inclusion and exclusion.

Several vignettes from in-depth, open-ended interviews with Lebanese citizens about their experiences in accessing and attempting to access health care, schooling, and other social benefits from sectarian parties and politicians illustrate what it means to be included or excluded from partisan welfare networks. ${ }^{11}$ The case of a Sunni woman who lives in Beirut is representative of the experiences of hard-core supporters of the Future Movement, a predominantly Sunni political party. The woman emphasized that she and her family receive extensive benefits from the Hariri Foundation, one of the party's affiliated welfare institutions, on a regular basis, including medical services as well as cash and food handouts. She reiterated her family's total commitment to the party and its leaders. ${ }^{12}$ Another Sunni woman, whose son works for a security agency linked to the Future Movement, also highlighted the benefits her family receives for its visible support for the organization. In return for his service, including his participation in a protomilitia during street clashes in May 2008, he receives a modest monthly salary and regular portions of food assistance. ${ }^{13}$

For the most ardent supporters of Hezbollah, the stream of welfare benefits is even more generous. The party's most extensive and continuous social programs have always been reserved for its core cadres and, especially, the families of "martyrs" and those wounded in its struggles with Israel, who make the largest sacrifices for the party. Of all the party officials whom I interviewed, the representatives of Hezbollah were the most forthright in detailing whom they target with their distinct welfare programs. For example, the Martyr's Program (Mua'asisat Al-Shahid), exclusively supports the families of fighters who have died or were injured in conflict with Israel (Al-Ahd [weekly publication of Hezbollah], August 30, 1991; Qassem 2005:60-61). ${ }^{14}$ Beyond party cadres, supporters receive benefits on preferential terms. Core activists of the party generally receive services in Hezbollah institutions, such as its hospitals, clinics, and schools, rather

11. This section draws on interviews conducted by a team of Lebanese graduate students with 135 lower-income Lebanese citizens. The interviewers and interviewees, whose real names and other identifying information are not provided, were matched by ascribed sectarian affiliation (see Cammett 2014).

12. Interview by Zina Sawaf of a Sunni woman, Beirut (Tariq elJedideh), October 23, 2007. An interview with another Sunni woman in this neighborhood yielded similar findings (by Zina Sawaf, Beirut [Tariq el-Jedideh], December 12, 2007).

13. Interview by Zina Sawaf of a Sunni woman, Beirut (Aisha Bakkar), November 17, 2007.

14. Author interviews of the director of Al-Qard Al-Hassan and an official of the Islamic Health Unit, Hezbollah, Haret Hreik, June 19, 2004. than programs explicitly reserved for certain eligible categories, such as those for martyrs and the wounded. But individuals and families whose political sympathies for the party are well known and demonstrated through repeated actions receive special treatment. ${ }^{15}$

Similar patterns are visible in the welfare programs of other sectarian groups, such as the predominantly Shi'a Amal Movement and the major Christian parties. During the civil war, when Christian parties such as the Kataeb and Lebanese forces had far more developed welfare programs than in the postwar period, their first priority was reserved for militia members. Fighters and their families received financial support and free medical services (Al-Maseera [publication of the Lebanese forces], April 17 and December 7, 1982; September 4, 1984). Beyond militia fighters, hard-core activists received the most extensive benefits. Thus, political connections have long been a strategy for coping with conditions of human insecurity and political instability.

Not all needy families, however, are incorporated into stable welfare networks. The testimonies of those who are not, whether by choice or otherwise, reveal the sense of precariousness that people experience under these circumstances. For example, a woman from a town on the outskirts of Sidon in South Lebanon noted that her husband receives free medical treatment in a government hospital for a chronic disease. The hospital staff, however, told him that he had to pay for medications himself, posing an enormous financial burden on the family. Although she expressed her gratitude for the services of public institutions and subsidized nongovernmental clinics, she finds their assistance to be insufficient, especially for chronic cases like that of her husband. She felt that her family's situation would be more sustainable had she and her husband established a close relationship with local politicians and political groups.

In discussing their attempts to access social benefits from agencies linked to the sectarian parties, interviewees emphasized that a proven track record of partisan support was essential for access to welfare. Lebanese citizens who are not active Hezbollah supporters claimed that they felt excluded from the party's social programs, whereas ardent supporters receive the assistance they need. ${ }^{16}$ Similarly, other interviews confirmed that Hezbollah distinguishes among in-group members in predominantly Shi'a areas, favoring core supporters over others. For example, a Shi'a man who resides and votes in Nabatiyyeh, a predominantly Shi'a city in the south that was once a stronghold of Hezbollah's former rival, the Amal Movement, claimed that he was told to seek aid elsewhere because he did not have a demonstrated history of supporting the party, he previously worked for Amal, and he did not

15. Author interviews of the director of the research center, Haret Hreik, January 9, 2008, and an official of Educational Programs, Mabarrat, Bir Hassan, January 17, 2008.

16. Interview by Salwa Maalouf of a Christian man, Beirut (Ashrafieh), November 16, 2007. 
present himself as sufficiently pious. According to the interviewee, Hezbollah carefully screens applicants for social assistance and is particularly attentive to the political behavior and allegiances of in-group members. ${ }^{17}$

The story of Mr. Hassan illustrates in painful detail the pressures and stresses associated with exclusion from partisan and other welfare networks. A man in his late 40s, Mr. Hassan originally comes from Baalbek, a city in the Beqaa region of Lebanon, and now resides in the southern suburbs of Beirut, which is often termed a "Hezbollah stronghold" in the popular press although not all residents are supporters of and activists in the party. Married and a father of four, he has held various jobs in order to make ends meet, and his financial situation is precarious. In an interview to discuss his experiences in accessing social assistance, Mr. Hassan recalled a heartbreaking story about his efforts to find medical care for his gravely ill 1-month-old son when he lived in the Beqaa region of Lebanon.

I want to tell you what we are suffering from in everyday life. ... I don't have an education. I worked in Baalbek in construction. My first child was born 2 months premature, and I suffered a lot because of that. I was getting paid 15,000 lira [US\$10] per day, and I had to pay for rent and for the baby's expenses. I sought help from people [and organizations] there in the region-Hezbollah and its Islamic Health Unit — and, at the end of every month, I found myself in debt because my job was sporadic. I worked on farms and in gas stations. Anyway, I had another child, a daughter, and then another son. When my second son was 1 month and 10 days old, he became very ill, but the doctors did not know what was wrong with him. He was struggling between life and death. I finally took him to a hospital in Baalbek. A doctor there went crazy when he saw my son and asked, "Who was treating him?!" I had been treating my son for a month in another hospital, but my son was on the verge of dying. I took him to another hospital that insisted I pay 800,000 lira [US\$533], and I only had 20,000 lira [US\$13]. My son got worse, and my family took him to a doctor who said that he is as good as dead and that we should take him to the hospital to try to save him, if this were even possible. I went to the hospital and found that they did not start to treat my son because they were waiting for the 800,000 Lira. The doctor would not agree to wait for the money. He told me that I needed to buy him medicine and I only had 15,000 lira [US\$10] in my pocket. I went to the pharmacy to buy the medication, and it turned out that it cost 72,000 lira [US\$48]. I told the pharmacist that I don't want the medication-I have my God. I went back to the doctor and told him that I did not have the money, but he told me that I needed to pay before he would treat my son. I went out of the hospital, and I did not know where to go;

17. Interview by Lamia Moghnie of a Shi'a beneficiary, Bir Hassan, November 10, 2007.
I thought that my son was as good as dead. Then I thought to go to the office of Al-Sayyid Fadlallah..$^{18}$ I walked because I didn't have the money to hire a taxi, but then, as if Allah were taking care of me, a guy parked nearby told me that he would drive me in his car and that he would give me $\$ 100$ toward my son's medical treatment.

Eventually, Mr. Hassan was able to obtain medical care for his baby through the assistance of generous individuals and charities in the Shi'a Muslim community. Although he was fortunate and his son survived, the effort of obtaining medical care was grueling, and he was forced to live with the fear that his child would die because of delayed treatment as a result of his financial situation and the lack of an institutionalized social safety net.

Mr. Hassan's experience highlights the potential consequences of marginalization from welfare networks in the context of Lebanon's fragmented welfare regime. Because he was not an activist in the parties that dominated politics in his area, he was not received at their medical institutions and could not rely on their intermediation to arrange immediate care for his son. For those who lack connections or are excluded from partisan networks, the efforts exerted to meet their basic needs take a toll. The information gathering and sheer tenacity required to access medical care and other social services can be physically and psychologically draining. The lack of certainty about whether such efforts will actually pay off is also a persistent source of anxiety. Furthermore, as many interviewees attested, seeking support from charitable institutions and negotiating with bureaucrats to receive social entitlements entail a loss of dignity and engender concerns about social reputation. One woman emphasized that she does not want anyone in her area to know that she goes to institutions for help because her neighbors will speak negatively about her and her daughters. Another woman said that she hesitates to seek social assistance directly from institutions; rather, she feels more comfortable when organizations approach her at her home in order to avoid embarrassment within her community. Perceived mistreatment at charitable institutions exacerbates this sense of humiliation. For example, a woman claimed that she had to stay in line for hours while a staff member distributing aid shouted at the applicants, making her feel disrespected. She also described similar treatment at a municipal health clinic. While it is impossible to corroborate her account, a perceived loss of dignity in efforts to receive social assistance was a regular theme in these interviews.

Lebanese citizens who are excluded from partisan welfare networks are not, however, helpless victims. Those in need of

18. Ayatollah Mohammed Hussein Fadlallah, who died in July 2010, was a prominent Shi'a cleric. His organization, Mabarrat, is a major Shi'a religious charity that runs hospitals, clinics, schools, religious centers, and other social and cultural programs throughout predominantly Shi'a parts of Lebanon. 
assistance are resourceful (Bayat 2010) even if they lack the partisan connections that are so valuable in Lebanon's patronage-based system. Reliance on personal connections is a crucial strategy. For example, a Lebanese woman who lives in the Sabra neighborhood of Beirut, a low-income area in Beirut that houses a large Palestinian camp, emphasized the value of her family's personal ties to an employee at a wellregarded private hospital in Beirut.

We have a very close friend, a very dear sister-we consider her a sister, we do not consider her a friend. She is a specialized nurse [at the hospital]. This brings a lot of benefits. She helps us a lot. ... She also helps us a lot with respect to the AUH [American University Hospital]. They all know her, they all like her. It still allows us to go, and she will help us with the treatment, of course, with the exams.

Underscoring the value of personal ties, another woman claimed, "If one has your back, it will do so many things for your situation."

\section{Welfare, Sectarianism, and the Experience of Urban Poverty in Lebanon}

As the preceding accounts imply, welfare provision by sectarian parties can affect the well-being of individuals and families, particularly with regards to access to social services and benefits. Beyond this, this phenomenon also has broader implications for the politics of welfare in the contemporary era in which states are no longer (or never were) major providers of services or guarantors of social protection. First, in the case of Lebanon, social provision by identity-based parties highlights a form of welfare politics operating at the "margins of the state" (Das 2004). In particular, the dual roles of sectarian power brokers as participants in the state and as nonstate providers blur the boundaries of public and private, often purposively. This simultaneous straddling of the state and nonstate realms complicates citizen experiences of accessing their "rights" and meeting their basic needs. For some, especially those who are not firmly recognized as core supporters or activists, attempts to access benefits, even those that are ostensibly the rights of citizenship, can be frustrating, exhausting, and demoralizing. Second, sectarian parties play a contradictory role as alleviator and perpetuator of structural violence. Third, the provision of social services by sectarian parties fuels the hyperpoliticization of welfare but at the same time undercuts forms of collective mobilization that might produce a more equitable system or at least one that is less stratified by sectarian cleavages, which overlap with but are by no means synonymous with socioeconomic class lines. Finally, the patterns of welfare outreach by sectarian organizations construct and/or entrench social inequalities. All of these factors shape the ways in which the poor, as well as the newly poor or downwardly mobile elements of society, navigate the terrain of public, private, and nonstate providers of social welfare. I will briefly elaborate each of these points.

First, the blurriness of the state/nonstate boundary in Lebanon manifests itself in the ways that the poor actually experience the welfare regime. Sectarian organizations operate their own self-funded and administered welfare networks. At the same time, representatives from these same groups occupy political offices from the highest to the lowest level, and all of the major parties have access to public resources to fund aspects of their social programs and mediate access to public entitlements. People wishing to attain their "rights" and those who lack the resources to meet their social needs through private markets must engage with intermediaries who either represent or have connections to the major sectarian parties, the dominant forces in Lebanese politics. Regardless of the laws on the books, political sectarianism shapes their processes of obtaining social services, including ones that are supposed to be public entitlements. ${ }^{19}$

This manifestation of politics at the margin of the state generates an interesting paradox. On the one hand, Lebanese people know that official laws do not guarantee rights. Obtaining virtually any service or avoiding a duty of citizenship require wasta, or connections with the right officials. Thus, the concept of membership in a community governed by a state with predictable and impartial rules is not a real, lived experience, and therefore, for most it is an abstraction. The phrase mafee dawla (there is no state) is a common refrain in everyday conversation and was repeated by many interviewees. At the same time, citizens express outrage at the failures of the state to deliver, indicating that they retain an ideal standard of stateness in their minds against which they benchmark government performance. Thus, despite the fact that they do not interact with state bureaucracies and institutional representatives in predictable, rule-bound ways, Lebanese citizens articulate high expectations of their state.

Second, the ways in which demonstrated political loyalties mediate access to welfare points to another form of social stratification - partisanship - that interacts with socioeconomic class to produce a form of "structural violence" (Farmer 1996). In the example of welfare provision by identity-based parties, the main protagonists are locally embedded actors rather than states or international organizations operating in the context of global inequalities. As described above, sectarian providers emanate from a long tradition of religious charity in the countries of the former Ottoman Empire and dominate the terrain

19. Another example beyond the welfare regime concerns the electoral system. In Lebanon, there is no preprinted ballot, enabling parties to supply their own ballots to prospective voters in advance and even right in front of polling stations. This not only helps them to gain more votes but also facilitates the vote-monitoring process, increasing citizen compliance in the vote-buying process. Under current laws, these practices are legal, but effectively they give rise to a large and complex economy of vote buying during electoral cycles (Doumit and Geha 2013). 
of nonstate social welfare provision in Lebanon. Whereas in most postcolonial states in the Middle East, newly independent governments established robust public welfare infrastructure, an analogous system never fully emerged in Lebanon, thereby entrenching the role of nonstate actors in social provision far more than in neighboring countries. ${ }^{20}$ Sectarian providers therefore represent cultural forms that make "common sense" to people (Rao and Walton 2004:8). But again, norms of stateness have diffused among the Lebanese population as evident in popular discussions of governance and echoed in the rhetoric of politicians who call for more robust state infrastructure even as their actions undercut government effectiveness.

The key role of sectarian parties as welfare providers and brokers recalls critiques of local development and decentralization policy schemes on the grounds that they are subject to elite capture. On the one hand, development policy increasingly calls for the promotion of locally appropriate, community-based development schemes. The most effective development initiatives incorporate attention to local social relations and adopt a "culturally aware approach to public action" (Rao and Walton 2004:8). In order to promote access to social services, this may entail partnering with communitybased organizations, which are presumed to be well placed to understand and meet the needs of local residents. On the other hand, local embeddedness does not guarantee equitable and impartial access to basic services. Sectarian organizations, among other providers who are well entrenched in the communities they serve, hold power over those who seek their assistance, as the preceding discussion indicates. Thus, even if they are not "corrupt" and do not funnel resources to their cronies, they construct and perpetuate hierarchical social relations in the politics of welfare access. In theory, "culturally based inequities" can be overcome through social mobilization and the "use of democratic processes to foster debate," but this process can be fraught with difficulties (Rao and Walton 2004:11). The role of sectarian parties in the political system effectively weakens or preempts grassroots efforts to alter local power hierarchies.

Third, the provision of social welfare by sectarian parties affects the political lives of the poor and needy. On the one hand, the involvement of sectarian parties in the direct provision of services and in brokering access to third-party benefits fuels the hyperpoliticization of welfare. As described above, political criteria, including levels of partisan activism and demonstrated loyalties, are factored into the welfare exchange, affecting both the provider's allocation of benefits and the choices that people make about where to seek services in the first place. The fact that sectarian parties are the most important vehicles for "democratic" representation

20. A Lebanese participant at a seminar where I presented some of my work once remarked, "This is just how things are done and always have been done in Lebanon. We turn to our communities for welfare." and social mobilization ensures that the provision of public goods and social services is especially politicized. ${ }^{21}$

On the other hand, sectarian parties undercut possibilities for political mobilization aimed at nonsectarian visions of the polity through multiple mechanisms. These parties mask or at least commingle overtly political actions, such as efforts to control state institutions and to exert social control, with less overtly political behaviors and even ostensibly "apolitical" charitable and humanitarian motivations. As noted above, representatives of sectarian welfare associations take pains to emphasize the nondiscriminatory eligibility criteria of their programs and frequently invoke humanitarian norms. In part through their control of and influence over state institutions and policies, sectarian organizations perpetuate a welfare regime that compels the poor and downwardly mobile to devote their full attention to meeting their basic needs, further obviating their capacity and perhaps will to engage in efforts to seek social and political transformation of the political and economic systems. The penetration of society through the creation of overlapping associations and interest groups by sectarian parties and their affiliates undercuts the efforts of activists to construct cross-sectarian, class, and interestbased associations (Clark and Salloukh 2013; Hamzeh 2001; Kingston 2013).

Officials from sectarian parties straddling the state/nonstate boundary rue the absence of the state in their public pronouncements, but they effectively hinder the capacity of the state to carry out what have come to be seen as its basic functions, including the provision of social services. Profiting from the weakness of state capacities - a phenomenon that they themselves help to perpetuate-sectarian groups establish and reinforce their control over everyday social and political life through the provision of social benefits. Social welfare, then, not only concerns the ways in which people meet their basic social needs; where public welfare functions are underdeveloped and ethnoreligious organizations provide social welfare, service provision both constitutes and reproduces the politics of sectarianism.

Finally, the provision of social welfare by sectarian parties contributes to the construction and consolidation of social inequalities along partisan and ethnoreligious lines and, in so doing, may strengthen social divisions in Lebanon's divided society. The very act of providing services may help to constitute or at least reinforce identity-based cleavages by establishing who is included in and excluded from social safety nets. Social welfare involves an obvious material exchange in which the beneficiary receives assistance to meet his or her family's basic needs. But the less obvious immaterial

21. Other providers who are less overtly tied to the political system also contribute to the politicization of social welfare in Lebanon. E.g., religious charities are often connected to if not controlled by the major sectarian parties, and, as some interviewees attested, access to their services may be conditional on particular forms of publicly expressed piety. 
dimensions of this relationship arguably serve a more profound community-building function. Social welfare provision brings a sense of security and psychological comfort that is especially valuable to beneficiaries of more limited means who, by definition, lead more precarious lives. This is all the more meaningful when states do not offer basic social protection schemes for their populations. By signaling who is a member of a protected group, the provision of basic services is an act of community building. Discriminatory access to welfare goods can therefore create new inequalities or further entrench existing inequalities and can even strain social cohesion. Taken to the extreme, the linkage between political identity and access to basic services has disturbing implications for social justice premised on perhaps idealized notions of equality before the law.

If political affiliation and behavior mediate access to social assistance, people - and particularly low-income families who need it most - may not be able to meet their basic needs when they are not perceived as loyal partisans. This highlights an additional political factor that shapes public wellbeing, at least in some contexts. In analyzing the determinants of health, for example, the public health literature has traditionally privileged individual demographic factors such as age, education, gender, and socioeconomic status. The broader social and political determinants of health have only recently attracted more attention (Marmot and Wilkinson 2003), and even then they tend to focus on macrolevel, structural factors rather than the "micropolitics" of access to basic services (Chen and Cammett 2012).

That said, social provision by sectarian organizations can also have detrimental effects on a macrolevel. If the provision of social benefits has political payoffs - and evidence shows that it does (Cammett 2014, chap. 6; LCPS 2000)then political parties have incentives to create their own welfare institutions or to take control of public programs through intermediation and brokerage roles. The creation of multiple networks of social provision linked to a different political organization leads to fragmented welfare regimes. While it is true that nonstate organizations are most likely to launch welfare operations where state programs are undeveloped in the first place, the emergence and consolidation of nonstate providers encourages further fragmentation of the welfare system and hinders longer-term efforts to construct nationally integrated welfare regimes. Furthermore, given the state's minimal role in the direct provision of services, there are ample opportunities for nongovernmental providers to create their own social institutions that are not well regulated by a central authority and that do not effectively coordinate their activities among each other. In the Lebanese health sector, this has been manifested in inefficiencies in the overall public health regime as well as inequalities in access to medical care, although evidence indicates that the various initiatives by the Ministry of Public Health have mitigated these effects in recent years (Ammar 2009). Inefficiencies and inequalities are also visible in the educational sector. Nonstate providers, including political parties and religious charities, have launched their own school systems with little regard for regional disparities in the distribution of educational facilities.

Control over schooling by ethnic or sectarian parties also has important implications for socialization and the longterm prospects for forging a sense of national political community. In divided societies, the stakes are particularly acute, as such groups may promote distinct understandings of national history and hinder the construction of a coherent national identity in future generations (Anderson 1991; Doumato and Starrett 2006; Freedman et al. 2004; Kaplan 2006; Levy 2004; Podeh 2000). In turn, the fragmentation of political identities and, hence, allegiances can undercut the provision of public goods in the long term, a self-reinforcing process (Habyarimana et al. 2009; Miguel 2004). If a feeling of solidarity based on a shared identity is critical for cooperation and joint action to pursue common goals (Lieberman 2003; Singh 2010; Tsai 2007), then the fragmentation of identities within a national territory may inhibit efforts to establish broader, more universalistic public welfare functions.

These micro- and macrolevel consequences, however, should not suggest that the provision of welfare by sectarian parties is uniformly detrimental to public well-being. Rather, it is essential to view the phenomenon in its entirety by adopting a more nuanced and contextualized perspective exposing its internal contradictions. In studying the social welfare programs of sectarian parties - particularly from my own particular vantage point-I have grappled with the question of how to incorporate normative considerations. Depicting the activities of sectarian parties as uniformly "bad" or "good" clearly misses some of the ambiguities of their role in the Lebanese welfare regime. This is most obvious at the individual level. Within sectarian groups running their own welfare agencies, staff members have complex motivations for working at these institutions, whether to serve the poor, to expand their patient load at their own private practices, or to enhance local support for their preferred political party, among other goals. Contingent on the quality and availability of services, beneficiaries can meet their basic needs at relatively low cost, giving them choices that might not otherwise be present in a welfare regime with many gaps.

At the system level, too, the goals and, more importantly, the effects of social provision by these groups are complex. As one representative of a nonsectarian social service organization claimed, "Without these groups, Lebanon would be poorer than India." His comment reflected the realities of the Lebanese social safety net, which has many holes, and the importance of political and religious providers in addressing social needs. Governments in many developing countries simply lack the capacity to provide for their own populations, whether because of lack of material resources or administrative deficiencies. As many have argued, NGOs of diverse orientations therefore play a key role in providing basic public goods and empowering citizens to meet their basic needs (Brinckerhoff 1999; Brown 1998; Salamon 1995). This 
is especially true in postconflict societies such as Lebanon, where the experience of war has further depleted public resources and undercut state institutions. Thus, sectarian groups may fill in gaping holes in the Lebanese welfare regime, although their efforts may perpetuate or perhaps even create these holes in the first place, producing and entrenching larger divisions along sectarian and class lines.

The welfare agencies run by sectarian organizations and the role they play in mediating access to essential service: meet the needs of some poor and vulnerable components of society who live tenuous lives and whose ranks are growing as inequality rises and the pressures of the regional humanitarian crisis in neighboring Syria spill over into Lebanon. In so doing, however, they reinforce the status quo because the boundaries of inclusion and exclusion established in their patterns of welfare outreach entrench existing social inequalities. Their welfare activities raise additional issues with longterm implications. While they fill a need in the "absence of the state," the welfare engagement of sectarian parties perpetuate state weakness even as they control the levers of the state, complicate the experience of gaining access to social benefits, and consolidate the foundations of the sectarian power-sharing system that limits the possibilities for social transformation toward another vision of the social order.

\section{References Cited}

Ammar, Walid. 2009. Health beyond politics. Beirut: Ministry of Public Health, Government of Lebanon.

Anderson, Benedict. 1991. Imagined communities. London: Verso.

Bayat, Asef. 2010. Life as politics: how ordinary people change the Middle East. Stanford, CA: Stanford University Press.

Bebbington, Anthony, S. Hickey, and D. Mitlin. 2008. Can NGOs make a difference? the challenge of development alternatives. London: Zed.

$\rightarrow$ Brinckerhoff, Derick. 1990. Exploring state-civil society collaboration. Nonprofit and Voluntary Sector Quarterly 28:59-86.

Brooks, Sarah. 2009. Social protection and the market: the transformation of social security institutions in Latin America. Cambridge: Cambridge University Press.

Brown, L. David. 1998. Creating social capital: nongovernment development organizations and intersectoral problem solving. In Private action and public goods. W. W. Powell and E. S. Clemens, eds. Pp. 228-244. New Haven, CT: Yale University Press.

Cammett, Melani. 2014. Compassionate communalism: welfare and sectarianism in Lebanon. Ithaca, NY: Cornell University Press.

$\rightarrow$ Cammett, Melani, and Sukriti Issar. 2010. Bricks and mortar clientelism sectarianism and the logics of welfare allocation in Lebanon. World Politics 62(3):381-421.

Cammett, Melani, and Lauren M. MacLean, eds. 2014. The politics of nonstate social welfare. Ithaca, NY: Cornell University Press.

Chaoul, Melhem, Hanna El-Hajj, Farid El-Khazen, Marguerite Helou, Tristan Khayyat, Salim Nasr, and Hoda Rizk, eds. 2001. Intikhabat An Niyabiyya fi Lubnan 2000 been Al-'Tada wa Al-Taghayar [The 2000 Parliamentary elections in Lebanon: between reproduction and change]. Beirut: Lebanese Center for Policy Studies.

Chen, Yen-Ting, and Melani Cammett. 2012. Informal politics and inequity of access to health care in Lebanon. International Journal for Equity in Health 11(23):1-8.

$\rightarrow$ Clark, Janine, and Bassel F. Salloukh. 2013. Elite strategies, civil society, and sectarian identities in postwar Lebanon. International Journal of Middle East Studies 45(3):731-749.

Corm, Georges. 1991. Liban: hégémonie milicienne et problème de rétablis sement de l'etat. Maghreb-Machrek 131:13-25.
Das, Veena. 2004. The signature of the state: the paradox of illegibility. In Anthropology in the margins of the state. Veena Das and Deborah Poole, eds. Pp. 225-252. Santa Fe, NM: School of American Research Press.

Doumato, Eleanor Abdella, and Gregory Starrett, eds. 2006. Teaching Islam: textbooks and religion in the Middle East. Boulder, CO: Rienner.

Doumit, Gilbert, and Carmen Geha. 2013. Election reform in Lebanon: an insider's perspective. http://www.academia.edu/3767789/Electoral_Reform in_Lebanon_An_Insider_Perspective.

Edwards, Michael, and David Hulme. 1996. Beyond the magic bullet: NGO performance and accountability in the post-Cold War world. West Hartford, CT: Kumarian.

Farmer, Paul. 1996. On suffering and structural violence: a view from below. Daedalus 125(1):261-283.

Fassin, Didier. 2012. Humanitarian reason: a moral history of the present. Berkeley: University of California Press.

Fawaz, Leila Tarazi. 1994. An occasion for war: Mount Lebanon and Damascus in 1860. Berkeley: University of California Press.

Ferguson, James. 1990. Anti-politics machine: development, depoliticization, and bureaucratic power in Lesotho. New York: Cambridge University Press.

Fox, Jonathan A., and David L. Brown. 1998. The struggle for accountability: the World Bank, NGOs, and grassroots movements. Cambridge, MA: MIT Press.

Freedman, Sarah Warshauer, Dinka Corkalo, Naomi Levy, Dino Abazovic, Bronwyn Leebaw, Dean Ajdukovic, Dino Djipa, and Harvey M. Weinstein. 2004. Public education and social reconstruction in Bosnia and Herzegovina and Croatia. In My neighbor, my enemy. E. Stover and H. M. Weinstein, eds. Pp. 226-247. New York: Cambridge University Press.

Fung, Archon, and Erik Olin Wright, eds. 2003. Deepening democracy: institutional innovations in empowered participatory governance. London: Verso.

Gates, Carolyn L. 1998. The merchant republic of Lebanon: rise of an open economy. London: Tauris.

Gough, Ian, Geof Wood, Armando Barrientos, Philipa Bevan, Peer Davis, and Graham Room. 2004. Insecurity and welfare regimes in Asia, Africa and Latin America. Cambridge: Cambridge University Press.

Habyarimana, James, Macartan Humphreys, Daniel N. Posner, and Jeremy M. Weinstein. 2009. Coethnicity: diversity and the dilemmas of collective action. New York: Russell Sage Foundation.

Haggard, Stephan, and Robert R. Kaufman. 2008. Development, democracy, and welfare states: Latin America, East Asia, and eastern Europe. Princeton, NJ: Princeton University Press.

$\rightarrow$ Hamzeh, A. Nizar. 2001. Clientelism, Lebanon: roots and trends. Middle Eastern Studies 37(3):167-178.

Hanf, Theodor. 1993. Coexistence in wartime Lebanon: decline of a state and rise of a nation. London: Centre for Lebanese Studies/Tauris.

Hanssen, Jens. 2005. Fin de siècle Beirut: the making of an Ottoman provincial capital. Oxford: Oxford University Press.

Harik, Judith Palmer. 1994. The public and social services of the Lebanese militias. Oxford: Center for Lebanese Studies, Oxford University.

Hickey, Samuel, and Giles Mohan, eds. 2004. Participation: from tyranny to transformation? London: Zed.

Hudson, Michael C. 1968. The precarious republic: political modernization in Lebanon. New York: Random House.

Kaplan, Sam. 2006. The pedagogical state: education and the politics of national culture in post-1980 Turkey. Stanford, CA: Stanford University Press.

Kingston, Paul. 2013. Reproducing sectarianism: advocacy networks and the politics of civil society in postwar Lebanon. Albany: State University of New York Press.

Korten, David C. 1990. Getting to the 21st century: voluntary action and the global agenda. New York: Kumarian.

Leenders, Reinhoud. 2004. Nobody having too much to answer for: laissezfaire, networks, and postwar reconstruction in Lebanon. In Networks of privilege in the Middle East. S. Heydemann, ed. Pp. 169-200. New York: Palgrave Macmillan.

Levy, Naomi. 2004. Identity politics in the schools of Bosnia-Herzegovina and Croatia. ISEEES Newsletter 21(2):8-24.

Lewis, David, and Nazneen Kanji. 2009. Nongovernmental organizations and development. London: Routledge.

Lieberman, Evan S. 2003. Race and regionalism in the politics of taxation in Brazil and South Africa. Cambridge: Cambridge University Press.

Makdisi, Ussama. 2000. The culture of sectarianism: community, history, and violence in nineteenth-century Ottoman Lebanon. Berkeley: University of California Press.

Mann, Michael. 1984. The autonomous power of the state: its origins, mechanisms and results. Archives Européens de Sociologie 25:185-213. 
Marmot, Michael, and Richard Wilkinson, eds. 2003. Social determinants of health. 2nd edition. Oxford: Oxford University Press.

$\rightarrow$ Mercer, Claire. 2002. NGOs, civil society and democratization: a critical review of the literature. Progress in Development Studies 2(1):5-22.

$\rightarrow$ Miguel, Edward. 2004. Tribe or nation? nation building and public goods in Kenya versus Tanzania. World Politics 56(3):327-362.

$\rightarrow$ Nichter, Simeon. 2008. Vote buying or turnout buying? machine politics an the secret ballot. American Political Science Review 102(1):19-31.

$\rightarrow$ Podeh, Elie. 2000. History and memory in the Israeli educational system: the portrayal of the Arab-Israeli conflict in history textbooks (1948-2000). History and Memory 12(1):65-100.

Qassem, Naim. 2005. Hizbullah: the story from within. London: Saqi.

Rao, Vijayendra, and Michael Walton, eds. 2004. Culture and public action. Stanford, CA: Stanford University Press.

Rudra, Nita. 2008. Globalization and the race to the bottom in developing countries: who really gets hurt? New York: Cambridge University Press.

Salamon, Lester M. 1995. Partners in public service: government-nonprofit relations in the modern welfare state. Baltimore, MD: Johns Hopkins University Press.

Salamon, Lester M., and S. Wojciech Sokolowski. 1999. Global civil society: dimensions of the nonprofit sector. Baltimore, MD: Johns Hopkins Center for Civil Society Studies.
Seekings, Jeremy. 2008. Welfare regimes and redistribution in the South. In Divide and deal: the politics of distribution in democracies. Ian Shapiro, Peter A. Swenson, and Daniela Donno, eds. Pp. 19-42. New York: New York University Press.

Singer, Amy. 2008. Charity in Islamic societies. New York: Cambridge University Press.

$\rightarrow$ Singh, Prerna. 2010. We-ness and welfare: a longitudinal analysis of social development in Kerala, India. World Development 39(2):282-293.

Smith, Steven R., and Michael Lipsky. 1993. Non-profits for hire: the welfare state in the age of contracting. Cambridge, MA: Harvard University Press.

Stokes, Susan C. 2005. Perverse accountability: a formal model of machine politics with evidence from Argentina. American Political Science Review 99(3):315-325.

Teamey, Kelly. 2007. Whose public action? analysing inter-sectoral collaboration for service delivery: literature review on relationships between government and non-state providers of services. Birmingham, UK: International Development Department, School of Public Policy, University of Birmingham.

Traboulsi, Fawwaz. 2007. A history of modern Lebanon. London: Pluto.

Tsai, Lily. 2007. Accountability without democracy: solidary groups and public goods provision in rural China. New York: Cambridge University Press. 